\title{
Determinants of farmer awareness of water governance across gender dimensions in smallholder irrigation schemes in KwaZulu-Natal Province, South Africa
}

\author{
SF Dlangalala' and M Mudhara' \\ 'School of Agricultural Earth and Environmental Sciences, University of KwaZulu-Natal, Private Bag X01, Pietermaritzburg 3209, South Africa
}

\begin{abstract}
Water is a vital resource for irrigated agricultural production. Its availability and accessibility are critical for alleviating poverty and achieving food security in rural households. However, smallholder irrigated agriculture in South Africa faces limited water supply emanating from scheme governance problems, with weak institutional arrangements that fail to equitably and effectively govern water resources. South African water policy has been transforming over the years. However, statutory laws remain unknown in smallholder irrigation schemes. This study sought to assess farmer awareness of water governance and identify the determinants of farmer awareness of water governance dimensions across gender dimensions in Mooi River, Tugela Ferry, and Ndumo irrigation schemes. The study employed principal component analysis to generate water governance indices, that is, formal institutions, the existence and effectiveness of scheme constitutions, scheme committees and enforcement of informal rules in the scheme. The ordinary least square regression technique was then used to identify factors determining farmer awareness of formal and informal water institutions in the three irrigation schemes. The findings suggest that formal water institutions are unknown and factors such as household characteristics, scheme location, stakeholder participation and involvement in scheme decision-making processes significantly influence awareness of governance. Therefore, there is a need to raise farmer awareness of formal water institutions and to strengthen the informal institutions which are functional, recognised and in line with irrigation management transfer.
\end{abstract}

\section{INTRODUCTION}

Water is a vital resource for agricultural production, both irrigated and non-irrigated. Its availability and accessibility are critical for alleviating poverty and achieving food security in rural households. However, smallholder irrigated agriculture in South Africa faces limited water supply emanating from scheme governance problems and weak institutional arrangements that fail to equitably and effectively govern water resources (Denby, 2013). In many African countries, water has been traditionally acquired from open water sources such as natural springs, hand-dug wells or surface water; hence institutions regarding management were unknown (Schnegg and Bollig, 2016). This is because in the past, water rights were not important and were inferior to land rights. According to Tshuma and Monde (2012) and Muchara (2014), poor institutional arrangements and management in smallholder irrigation schemes (SISs) in South Africa make most of them dysfunctional. Therefore, water rights, water governance and institutional arrangements to control and regulate the use of water become extremely important. However, the nature of water and its properties in rural areas make the definition of water rights difficult and costly. Water rights are inherently linked to land rights because ownership of an irrigation plot automatically gives the right to irrigation water access.

South African water policy has transformed to address past racial imbalances in accessing water that were created by the apartheid government. In 1998, South Africa enacted the National Water Act (NWA) (Act 36 of 1998; RSA, 1998) with an intention to 'decentralise and integrate water management, create new local and regional institutions with equal representation, register and licence water use and finally to facilitate the emergence of a water rights market' (Denby, 2013 p. 2). In 2006, the water allocation reform (WAR) policy was implemented to reallocate water from the advantaged to economically disadvantaged individuals. However, the implementation of the NWA and WAR has been slow, and their expected outcomes have not been realised. For example, the compulsory licensing which is one of the mechanisms of the WAR programme has not been widely implemented (DWA, 2013). Likewise, although the NWA is recognised globally as progressive water policy, it is unknown in SISs (Denby, 2013). Meinzen-Dick and Nkonya (2005) argued that if the range and complexity of institutions governing the use of water resources are not understood, any efforts to improve water allocations will be ineffective and not yield the desired outcomes.

According to Gallaher and Heikkila (2014), water governance is about collective decisions and choices relating to the use and management of water resources that emerge through institutions. It encompasses the mechanisms of setting rules and institutions with which water resources are managed. Sokile et al. (2005, p. 1) defined formal institutions as 'the written ordinances created by the legislative council before the independence and contemporary legislation in one hand', while, informal water institutions are defined as 'the set of local, community-based practices that are normally determined by local customs, traditions, and culture of water use.'

\section{CORRESPONDENCE}

SF Dlangalala

\section{E-MAIL}

imbaliyamantungwa@gmail.com

\section{DATES}

Received: 14 December 2018

Accepted: 7 April 2020

\section{KEYWORDS}

farmer awareness formal institutions informal institutions principal components analysis smallholder irrigation schemes

\section{COPYRIGHT}

() The Author(s)

Published under a Creative

Commons Attribution 4.0

International Licence (CC BY 4.0) 
The study argues that both formal and informal water institutions are essential for the efficient and sustainable distribution of irrigation water among users since formal and informal water institutions are interlinked (Sokile et al., 2005; Deribe, 2008). Unfortunately, statutory laws are unknown at scheme level due to insufficient communication between government officials and irrigators (Meinzen-Dick and Nkoya, 2005). In the Inkomati catchment management area (South Africa), Mehta et al. (2014) found that smallholder farmers lack knowledge of the NWA, formal water policy and other formal channels for accessing water, reflecting poor communication between the national government, local government and water users at the farm level. Consequently, irrigators in SISs define their own rules and regulations regarding water use and perceived customary laws to be stronger and powerful than formal laws.

Therefore, the study sought to assess farmer awareness of water governance and identify the determinants of farmer awareness of water governance dimensions across gender dimensions in Mooi River, Tugela Ferry and Ndumo irrigation schemes, South Africa. The study was undertaken as part of a project (K5/2556/4) initiated, managed and funded by the South Africa Water Research Commission (WRC) entitled, 'Assessment of policies and strategies for the governance of smallholder irrigation farming in KwaZulu-Natal Province, South Africa'.

\section{METHODS}

This section provides a brief explanation of the research methods used in this study, i.e., the study area, data collection and sampling techniques, empirical model and the variables (explained and explanatory) used in the analysis.

\section{Study area}

The survey was undertaken in Mooi River and Tugela Ferry Irrigation Schemes located in Msinga Local Municipality in Umzinyathi District, and Ndumo Irrigation Scheme located in Jozini Local Municipality in Umkhanyakude District. Mooi River Irrigation Scheme (MRIS) covers approximately 600 ha made up of 15 Blocks (Block 1 - 15) which serve about 850 irrigators. The scheme primarily depends on the Mooi River for water and uses the canal to convey water to the field. Tugela Ferry Irrigation Scheme (TFIS) has the highest number of beneficiaries (1 500 irrigators). It covers approximately 800 ha made up of 9 Blocks (Block 1, 2, 3, 4A, 4B, 5, 6, 7A and 7B). The scheme is fed by Tugela River and uses the canal, diesel, and electric pumps to convey water to the field. Finally, Ndumo Irrigation Scheme (NIS) is a relatively large irrigation scheme (approximately 1 500 ha comprising of Phase 1 and 2) serving relatively fewer beneficiaries (100 irrigators) compared to the other irrigation schemes. The scheme abstracts water from Pongola River and conveys it to the plots through an electric pump. All the study irrigation schemes are farmer-managed with minimal or no governance assistance. The different location of the schemes, variation in and farmer awareness of water governance across the schemes informed the choice of irrigation schemes.

\section{Data collection tools and sampling techniques}

Primary data used in this study were collected through focus group discussions, key informant interviews, and a structured household questionnaire. The household questionnaire was pre-tested, modified accordingly and administered by trained Zulu-speaking enumerators. Survey respondents were selected using a stratified and systematic random sampling technique, where the strata were the blocks within the schemes. A sample of 274 irrigators was drawn from the three irrigation schemes by selecting every fifth irrigator. In stratified random sampling, samples are randomly drawn from non-overlapping strata of the population (Singh and Chaudhary, 1986), whereas in systematic sampling, samples are drawn by selecting the first unit with the help of random numbers, while the rest get selected automatically (Singh and Chaudhary, 1986). Using the combination of the two sampling techniques made it easier to draw more precise samples that are easy to execute and to ensure adequate representation to irrigators within the schemes (Singh and Chaudhary, 1986).

\section{Empirical model}

The study employed principal component analysis (PCA) and ordinary least squares (OLS). PCA was used to generate indices indicating formal and informal water institutions in SISs. OLS regressions were applied to identify factors influencing farmer awareness of formal and informal water institutions.

\section{Principal component analysis}

Likert scale type questions were asked to assess the major indicators of formal and informal water institutions, with farmers indicating whether they strongly disagreed, disagreed, were neutral, agreed or strongly disagreed. Index values increase from 1 to 5 if the respondent strongly agrees and decreases from 5 to 1 if the respondent strongly disagrees. Principal component analysis (PCA) was then used to generate indices for formal and informal water institutions.

\section{Ordinary least squares regression model}

The generated indices from the PCA were regressed against explanatory variables known to influence farmer awareness using ordinary least squares (OLS). The number of regression models to be estimated equals the number of the retained PCs, which captured different dimensions of water institutions. According to Gujarati and Porter (2009), the OLS regression model can be specified as:

$$
Y_{i}=\beta_{0}+\beta_{i} X_{i}+\mu_{\mathrm{i}}
$$

where $Y_{\mathrm{i}}$ is the water institution index for the $i^{\text {th }}$ irrigator; $X_{\mathrm{i}}$ is a vector of explanatory variables; $\beta_{0}$ and $\beta_{\mathrm{i}}$ are the vector of parameters to be estimated and $\mu_{\mathrm{i}}$ is the error term.

\section{Description of variables}

\section{Dependent variables}

The Kaiser-Meyer-Olkin (KMO), the measure of sampling adequacy, for formal and informal institutions, was at least 0.5, implying that PCA can be performed (Table 1) (Kaiser and Rice, 1974). Likewise, Bartlett's test of sphericity, which checks if the observed correlation matrix diverges significantly from the identity matrix $\left(H_{0}\right.$ : the variables are orthogonal) , were statistically significant $(p<0.001)$ implying that the variables were not perfectly correlated. Therefore, PCA can be performed efficiently. To retain the PCs, the study applied the Kaiser criterion which suggests that PCs with eigenvalues greater than 1 must be retained (Everitt and Hothorn, 2011). Three PCs representing informal, and one PC representing formal water institutions, respectively, were retained. Tables 1 and 2 present the generated PCs as indicators of formal and informal water institutions, respectively.

With reference to Table 1, the first three PCs retained explained $72.13 \%$ of the total variation in the data, cumulatively. The first PC had a higher explanatory power, explaining about $36.35 \%$ of variation in farmer awareness of formal water institutions. The second and third PC accounted for $18.72 \%$ and $17.07 \%$, respectively. PC1 is economically meaningful, as all its 
Table 1. Principal component analysis of the major indicators of formal water institutions at scheme leve

\begin{tabular}{|c|c|c|c|}
\hline \multirow[t]{2}{*}{ Description of variables } & \multicolumn{3}{|c|}{ Principal component } \\
\hline & PC1 & PC1 & PC1 \\
\hline Awareness of NWA & 0.902 & -0.169 & -0.095 \\
\hline Awareness of NWRS & 0.890 & -0.163 & -0.101 \\
\hline $\begin{array}{l}\text { Knowledge of government } \\
\text { aims }\end{array}$ & 0.596 & -0.057 & 0.484 \\
\hline Availability of water licences & 0.118 & 0.758 & -0.370 \\
\hline Availability of water rights & 0.156 & 0.610 & 0.682 \\
\hline Knowledge of any WUA & 0.427 & 0.343 & -0.411 \\
\hline Eigenvalue & 2.181 & 1.123 & 1.024 \\
\hline$\%$ of variance explained & 36.34 & 18.72 & 17.07 \\
\hline $\begin{array}{l}\text { Cumulative } \% \text { variance } \\
\text { explained }\end{array}$ & 36.34 & 55.06 & 72.13 \\
\hline $\mathrm{KMO}$ & \multicolumn{3}{|c|}{0.603} \\
\hline Bartlett test of sphericity & \multicolumn{3}{|c|}{$\sim \chi^{2}=372.542(p<0.001)$} \\
\hline$n$ & \multicolumn{3}{|c|}{274} \\
\hline
\end{tabular}

Note: Component loadings greater than $|0.40|$ are highlighted in bold print

coefficients are positive and have larger component loadings. Each variable represents formal institutions governing water in irrigation schemes. Therefore, the positive component loadings indicate that $\mathrm{PC1}$ represents farmer awareness of formal water institutions (FORMAL_INSTI), while PC2 indicates farmer possession of legal water requirements. The analysis will be performed on the first PC which is more economically meaningful.

The first retained PC in Table 2 explained $35.02 \%$ of the total variation in the major indicators of formal water institutions. PC1 is economically meaningful, as all its coefficients are positive and have larger component loadings. Each variable is closely related to farmer awareness of informal water institutions governing the scheme operations. Hence, it was named informal institutions (INFORMAL_INST ).

Irrigation schemes have rules developed for managing water resources, and those rules are stipulated in the constitution. For these rules to work effectively they need to be enforced. The second retained PC explained $21.81 \%$ of the total variation in the major indicators of informal water institutions. This $\mathrm{PC}$ is economically meaningful and closely related to farmer perceptions of rule enforcement in the scheme. Hence, the PC was named rule enforcement (RULE_ENF).

\section{Explanatory variables}

Studies that have been done on farmer awareness indicated that household characteristics, membership in farmer organisations, source of information, access to extension services and stakeholder participation are some of the influential factors to farmer awareness of national policies (Muatha, 2014; Okpeke et al., 2015; Duhan and Singh, 2017; Duhan and Dhingra, 2018). Therefore, this study predicted that farmer awareness of water institutions is influenced by household demographics, scheme location, stakeholder involvement in the scheme, participation in scheme leadership and in decision-making processes, membership in farmer organizations and accessible sources of information. However, the effects of factors influencing farmers awareness of water institutions vary across formal and informal water institutions. Table 3 provides a description of the variables included in the analysis.
Table 2. Principal component analysis of the major indicators of informal water institutions at scheme level

\begin{tabular}{lcc}
\hline Description of variables & \multicolumn{2}{c}{ Principal components } \\
\cline { 2 - 3 } & $\begin{array}{c}\text { PC1 } \\
\text { INFORMAL_INST }\end{array}$ & $\begin{array}{c}\text { PC2 } \\
\text { RULE_ENF }\end{array}$ \\
\hline $\begin{array}{l}\text { Presence of appropriate rules in } \\
\text { irrigation water management }\end{array}$ & 0.385 & $-\mathbf{0 . 6 6 7}$ \\
$\begin{array}{l}\text { Satisfaction with the current } \\
\text { executive committee }\end{array}$ & $\mathbf{0 . 6 2 5}$ & 0.069 \\
$\begin{array}{l}\text { Difficulties in rule enforcement } \\
\text { Fair penalties to }\end{array}$ & 0.227 & $\mathbf{0 . 7 9 7}$ \\
non-compliance & $\mathbf{0 . 7 5 1}$ & 0.071 \\
$\begin{array}{l}\text { Satisfaction with conflict } \\
\text { management in the scheme }\end{array}$ & $\mathbf{0 . 7 7 2}$ & -0.026 \\
$\begin{array}{l}\text { Eigenvalue } \\
\text { Variance explained (\%) }\end{array}$ & 1.751 & 1.091 \\
$\begin{array}{l}\text { Cumulative \% of variance } \\
\text { explained } \\
\text { KMO }\end{array}$ & 35.019 & 21.815 \\
Bartlett test of sphericity & 35.019 & 56.834 \\
$n$ & & \\
\hline
\end{tabular}

Note: Component loadings greater than $0.40 \mid$ are highlighted in bold print

Age: Age is one of the factors influencing the level of awareness. According to Duhan and Singh (2017), younger farmers read more from different information sources and are not as reluctant as older farmers to adopt changes in agricultural/water policies; hence are more aware compared to older farmers. They attributed this discrepancy to a different level of education obtained by the two groups. Therefore, in this study, older irrigators are anticipated to be least aware of formal water institutions and more likely to be aware of informal water institutions.

Gender: In SISs and the African culture women tend to be treated as inferior although they constitute the largest proportion of smallholder farmers. Women are usually denied access to attend meetings, workshops or training (Mudege et al., 2017). Sometimes they are held back by household activities they need to perform. According to Muatha (2014), male irrigators have a higher likelihood to be exposed to water institutions. Therefore, holding other factors constant, male irrigators are anticipated to be more aware of water institutions than female irrigators.

Level of education: According to Duhan and Dhingra (2018), literacy level and educational qualification influence levels of understanding and awareness of agricultural innovations. Less-educated irrigators are assumed to be less aware of water institutions. However, this is not always the case. SISs are dominated by older farmers with no formal education (EDUC_ LEVEL) but tend to be more aware of the scheme governance. A positive association between education and farmer awareness of formal institutions is expected, ceteris paribus.

Scheme location: The location of an irrigation scheme (municipality) can influence farmer awareness of water institutions through the extent of external stakeholder involvement in water resource management. Since the study irrigation schemes are in different local municipalities located under different tribal authorities, either a positive or negative influence on farmer awareness of water institutions can be expected.

The role played in scheme leadership: Irrigators who participate in scheme decision-making processes are more likely to be informed about formal institutions and community affairs. According to Mowo et al. (2013), local leaders are relatively better educated and are the ones who formulate local 
Table 3. The description of variables included in the analysis and their anticipated effects

\begin{tabular}{|c|c|c|}
\hline Variable & Description & $\begin{array}{c}\text { Anticipated } \\
\text { effect }\end{array}$ \\
\hline \multicolumn{3}{|c|}{ Explanatory variables } \\
\hline AGE & The age of an irrigator (years) & $-/+$ \\
\hline GENDER & $\begin{array}{l}\text { The gender of an irrigator }(1=\text { male; } \\
0=\text { otherwise })\end{array}$ & + \\
\hline EDUC_LEVEL & $\begin{array}{l}\text { The level of education an irrigator } \\
\text { has received ( } 1=\text { formal education; } \\
0=\text { otherwise) }\end{array}$ & + \\
\hline SCHEME_LOC & $\begin{array}{l}\text { Scheme location, the local } \\
\text { municipality where the irrigation } \\
\text { scheme is located ( } 1=\text { Msinga } \\
\text { Local Municipality; } 0=\text { Jozini Local } \\
\text { Municipality) }\end{array}$ & $+/-$ \\
\hline $\begin{array}{l}\text { ROLE}_{-} \\
\text {SCHMLED }\end{array}$ & $\begin{array}{l}\text { Role played in scheme leadership } \\
\text { ( } 1=\text { ordinary member; } 2=\text { block } \\
\text { committee; } 3 \text { = secondary } \\
\text { committee })\end{array}$ & + \\
\hline WATM_TRAIN & $\begin{array}{l}\text { Whether an irrigator have received } \\
\text { formal water management training } \\
(1=\text { yes; } 0=\text { otherwise })\end{array}$ & + \\
\hline WUA_MEMB & $\begin{array}{l}\text { Whether an irrigator is a member of } \\
\text { Water Users Association (WUA) ( } 1= \\
\text { yes; } 0 \text { otherwise) }\end{array}$ & + \\
\hline GOVT_INV & $\begin{array}{l}\text { Involvement of government } \\
\text { departments in the scheme } \\
\text { management (index) }\end{array}$ & + \\
\hline TRIBAUTH_INV & $\begin{array}{l}\text { Involvement of traditional } \\
\text { authorities in the scheme } \\
\text { management (index) }\end{array}$ & + \\
\hline INV_SCHMDEC & $\begin{array}{l}\text { Irrigator participation in decision- } \\
\text { making processes in the scheme } \\
\text { (index) }\end{array}$ & + \\
\hline INFO_SOURCE & Source of information (index) & + \\
\hline \multicolumn{3}{|c|}{ Dependent ariable } \\
\hline FORMAL_INST & \multicolumn{2}{|c|}{ Farmer awareness of formal water institutions (index } \\
\hline $\begin{array}{l}\text { INFORMAL_ } \\
\text { INST }\end{array}$ & \multicolumn{2}{|c|}{$\begin{array}{l}\text { Farmer awareness of the informal water institutions } \\
\text { in the scheme (index) }\end{array}$} \\
\hline RULE_ENF & \multicolumn{2}{|c|}{$\begin{array}{l}\text { Farmer perception about rule enforcement in the } \\
\text { scheme (index) }\end{array}$} \\
\hline
\end{tabular}

institutions through their leadership roles. This is because the block committee and secondary committee members are scheme leaders. Everything that has to do with farmers in SISs goes through the scheme committee, and if there is training or a workshop to be provided to farmers, scheme committee members are always expected to attend.

Training: Water management training is critical for improving water-use efficiency and sustainable use of irrigation water in SISs (Namara et al., 2010). Irrigators who have received water management training are more likely to be aware of formal water institutions, ceteris paribus. Water management training provided by the irrigation committee is likely to disseminate information on the intentions of informal water institutions. Therefore, water management training (WATM_TRAIN) is anticipated to be positively related to farmer awareness of formal and informal water institutions, ceteris paribus.

Farmer organizations: Farmer organizations serve as a convenient platform for farmers to disseminate agricultureand water-related information. Water user associations (WUA) are a formal farmer organization established as a strategy for establishing governance of the scheme and for disseminating information about formal water institutions (Manzungu, 2000; Sokile et al., 2005). It is therefore anticipated that membership in a WUA (WUA_MEMB) is expected to positively increase farmer awareness of both formal and informal water institution, ceteris paribus.

Stakeholder participation: Water resources in SA are managed through water legislation (NWA) focusing on ensuring equitable and sustainable allocation of water resources through authorization (licensing and registration) to avoid and control the risks of unsustainable water management (Namara et al., 2010). The involvement of government departments (GOVT_ INV) in irrigation schemes will inform irrigators about the formal NWA, its aims and strategies. Involvement of tribal authorities (TRIBAUTH_INV) is anticipated to increase farmer awareness of informal water institutions as they also play an important role in rule enforcement. Traditional authorities, particularly chiefs, have the power to influence rural farmers (Sokile et al., 2005; Deribe, 2008). Farmer involvement in decision-making processes in the scheme (INV_SCHMDEC) relating to water management activities is anticipated to raise farmer awareness of water institutions and thereby enhance decision-making capacity, ceteris paribus. In addition, Muatha (2014) asserted that farmer engagement in scheme decisionmaking processes also plays an important role in maintaining harmony among irrigators.

Source of information: Access to information plays a significant role in agricultural development (Mudege et al., 2017). The most important and easily accessible information sources in the study irrigation schemes include extension officers, media, irrigation committee, and fellow farmers. Among these information sources, extension officers and the media play an important role in providing information on national policies (Muatha, 2014). Holding other factors constant, the source of information (INFO_SOURCE) is expected to positively increase farmer awareness of both formal and informal water institutions.

\section{RESULTS AND DISCUSSION}

This section presents the study findings. It starts off by providing a brief description of household characteristics of the study and farmer awareness of formal water institution in MRIS, and TFIS, and finally gives an overview of the regression results.

\section{Descriptive statistics}

\section{Household characteristics}

The results obtained from the household survey conducted for the study irrigation schemes indicated that MRIS and TFIS are dominated by female, elderly farmers with an average age of 57 and 55 years, respectively, who had not acquired formal education (Table 4). The dominance of women in MRIS and TFIS can be attributed to the fact that irrigation farming is regarded as a female activity in Msinga, while males concentrate on cattle rearing and non-farm activities (Muchara, 2014; Sinyolo et al., 2014). On the contrary, Ndumo Irrigation Scheme is dominated by young irrigators with an average age of 46 years and who are better educated with a considerable proportion of irrigators with high school and tertiary levels of education (Table 4). Unlike in other SISs, Ndumo irrigators are predominantly male.

\section{Farmer awareness of water institutions across irrigation schemes}

The results presented in Table 5 indicate that most irrigators were not aware of formal water institutions (NWA, NWRS, and WUAs). Hence, the WUAs were non-existent. On average, 
very few irrigators indicated having received water management training in these schemes. Across the irrigation schemes, irrigators always participated in scheme decision-making if they were informed about the opportunity to do so by the irrigation scheme's institutions. Moreover, irrigators across the schemes $(\mathrm{MRIS}=4.44 ; \mathrm{TFIS}=3.62 ; \mathrm{NIS}=3.44)$ were satisfied with the involvement of traditional authorities in the scheme. Farmer awareness of formal water institutions showed statistically significant variation, meaning that the awareness differed across irrigation schemes. NIS irrigators are most aware and have received more water management training than those in the other two irrigation schemes. This could be attributed to the variation in the level of education acquired, the average age of irrigators and the availability of information sources across the schemes.

\section{Regression results}

With reference to Tables 6 and 7, the F-tests on all the estimated regression models were statistically significant $(p=0.001)$, implying that all the explanatory variables included in the models jointly had a meaningful influence on farmer awareness of formal and informal water institutions in MRIS, TFIS, and NIS. The variance inflation factors (VIFs) used to test for multicollinearity among variables were all less than 10 , indicating that multicollinearity was not a serious problem in the data set (Gujarati and Porter, 2009). Moreover, heteroscedasticity was accounted for by using robust standard errors in the OLS regression.

Table 4. Household characteristics across the study irrigation schemes

\begin{tabular}{|c|c|c|c|c|c|}
\hline \multirow[t]{2}{*}{ Variable } & \multirow[t]{2}{*}{ Description } & \multicolumn{3}{|c|}{ Irrigation scheme } & \multirow[t]{2}{*}{$x^{2}$} \\
\hline & & MRIS & TFIS & NIS & \\
\hline \multirow[t]{4}{*}{ Age group (\%) } & $20-35$ years & 10.1 & 7.5 & 32.4 & \multirow[t]{4}{*}{$* * *$} \\
\hline & $36-56$ years & 37.0 & 42.5 & 38.2 & \\
\hline & $57-69$ years & 34.5 & 35.0 & 23.5 & \\
\hline & $70-88$ years & 18.5 & 15.0 & 5.9 & \\
\hline \multirow[t]{2}{*}{ Gender (\%) } & Male & 15.8 & 12.5 & 67.6 & \multirow[t]{2}{*}{$* * *$} \\
\hline & Female & 84.2 & 87.5 & 32.4 & \\
\hline \multirow[t]{2}{*}{ Education (\%) } & No formal & 64.7 & 59.2 & 23.5 & \multirow[t]{2}{*}{$* * *$} \\
\hline & Formal & 35.3 & 40.8 & 76.5 & \\
\hline
\end{tabular}

Note: ${ }^{* * *}=p<0.01 ;{ }^{* *}=p<0.05 ;{ }^{*}=p<0.10 ; \mathrm{NS}=$ not statistically significant

Table 5. Farmer awareness of water institutions across irrigation schemes

\begin{tabular}{|c|c|c|c|c|c|}
\hline Water institution & Awareness & Irrigation scheme & & & $x^{2}$ \\
\hline & & MRIS & TFIS & NIS & \\
\hline \multirow[t]{2}{*}{ Awareness of NWA (\%) } & Agree & 14.2 & 1.7 & 29.4 & $* * *$ \\
\hline & Strongly agree & 2.5 & 0.0 & 17.6 & \\
\hline \multirow[t]{2}{*}{ Awareness of NWRS (\%) } & Agree & 10.0 & 0.8 & 14.7 & $* * *$ \\
\hline & Strongly agree & 1.7 & 0.0 & 14.7 & \\
\hline Knowledge of WUAs (\%) & Yes & 6.7 & 0.8 & 6.7 & * \\
\hline Member of WUA (\%) & Yes & 0.0 & 0.0 & 3.1 & $* *$ \\
\hline Water management training (\%) & Yes & 29.2 & 18.3 & 44.1 & *** \\
\hline
\end{tabular}

${ }^{* * *} p<0.01 ;{ }^{* *} p<0.05 ;{ }^{*} p<0.10$

Table 6. Factors influencing farmer awareness of formal water institutions in Mooi River, Tugela Ferry and Ndumo irrigation schemes, 2018

\begin{tabular}{|c|c|c|c|}
\hline \multirow[t]{2}{*}{ Explanatory variables } & \multicolumn{2}{|c|}{ FORMAL_INSTI } & \multirow[t]{2}{*}{ VIF } \\
\hline & Coefficient & Robust Std. Error & \\
\hline AGE & -0.001 NS & 0.004 & 1.34 \\
\hline MALE & $0.526 * * *$ & 0.191 & 1.31 \\
\hline FORMAL_EDUC & $0.335^{* * *}$ & 0.136 & 1.36 \\
\hline SCHEME_LOC & $-0.536^{* * *}$ & 0.291 & 1.34 \\
\hline WATM_TRAN & $0.399 * * *$ & 0.142 & 1.09 \\
\hline ROLE_SCHMLED & 0.079 NS & 0.180 & 1.14 \\
\hline GOVT_INV & $-0.012^{\mathrm{NS}}$ & 0.030 & 1.13 \\
\hline TRIBAUTH_INV & $0.037^{\mathrm{NS}}$ & 0.035 & 1.06 \\
\hline INV_SCHMDEC & $0.097^{* *}$ & 0.042 & 1.18 \\
\hline INFO_SOURCE & $-0.052^{\mathrm{NS}}$ & 0.056 & 1.19 \\
\hline _cons & $0.089^{\text {NS }}$ & 0.570 & \\
\hline Model summary & $\begin{array}{c}F \text {-stat }=6.90 ; p<0.001 \\
R^{2}=0.2358 ; n=274\end{array}$ & & Mean VIF $=1.21$ \\
\hline
\end{tabular}

Note: ${ }^{* * *}=p<0.01 ;{ }^{* *}=p<0.05 ;{ }^{*}=p<0.10 ;$ NS $=$ not statistically significant 
Table 7. Regression results of factors influencing farmer awareness of informal water institutions in Mooi River, Tugela Ferry and Ndumo irrigation schemes, 2018

\begin{tabular}{|c|c|c|c|c|c|}
\hline \multirow[t]{2}{*}{ Explanatory variables } & \multicolumn{2}{|c|}{ INFORMAL_INST } & \multicolumn{2}{|c|}{ RULE_ENF } & \multirow[t]{2}{*}{ VIF } \\
\hline & Coeff. & Rob. std err. & Coeff. & Rob. std err. & \\
\hline AGE & $0.001^{\mathrm{NS}}$ & 0.004 & $0.007^{\mathrm{NS}}$ & 0.004 & 1.30 \\
\hline MALE & $-0.171^{\mathrm{NS}}$ & 0.148 & $0.081^{\mathrm{NS}}$ & 0.155 & 1.31 \\
\hline FORMAL_EDUC & $-0.102^{\mathrm{NS}}$ & 0.113 & $0.221^{*}$ & 0.126 & 1.36 \\
\hline SCHEME_LOC & $-0.161^{*}$ & 0.188 & $0.415^{* *}$ & 0.195 & 1.37 \\
\hline WATM_TRAN & $0.117^{\mathrm{NS}}$ & 0.113 & $0.109^{\mathrm{NS}}$ & 0.128 & 1.09 \\
\hline ROLE_SCHMLED & $-0.203^{*}$ & 0.111 & $0.106^{\mathrm{NS}}$ & 0.137 & 1.13 \\
\hline GOVT_INV & $0.158^{* * *}$ & 0.032 & $0.007^{\mathrm{NS}}$ & 0.027 & 1.12 \\
\hline TRIBAUTH_INV & $0.307^{* * *}$ & 0.047 & $-0.053^{\mathrm{NS}}$ & 0.036 & 1.07 \\
\hline INV_SCHMDEC & $0.449 * * *$ & 0.072 & $0.185^{* * *}$ & 0.045 & 1.18 \\
\hline INFO_SOURCE & $-0.029^{\mathrm{NS}}$ & 0.063 & $-0.406^{* * *}$ & 0.047 & 1.20 \\
\hline _cons & $-2.249^{* * *}$ & 0.647 & $1.158^{* *}$ & 0.505 & \\
\hline Model summary & $\begin{array}{c}F \text {-stat }=8.55 ; p=0.001 \\
R^{2}=0.2940 ; n=274\end{array}$ & & $\begin{array}{c}F \text {-stat }=11.39 ; p=0.001 \\
\quad R^{2}=0.2613 ; n=274\end{array}$ & & Mean $\mathrm{VIF}=1.21$ \\
\hline
\end{tabular}

${ }^{* * *} p<0.01 ; * * 0.05 ; * p<0.10 ; \mathrm{NS}=$ not statistically significant

\section{Factors influencing farmer awareness of formal water institutions in smallholder irrigations schemes}

The regression model for the first PC had an $R^{2}$ of 0.2358 , implying that $23.58 \%$ of the variation in farmer awareness of formal water institutions is explained by the explanatory variables included in the model. The regression results indicated that, among the explanatory variables included in the model, male, formal education acquired, water management training, scheme location and farmer engagement in scheme decisionmaking processes had a positive and significant influence on farmer awareness of formal water institutions, except scheme location which had a negative association with farmer awareness of formal water institutions.

The estimated coefficient of 'male' was found to be positive and statistically significant $(p<0.01)$ as anticipated. This suggests that male irrigators were more aware of formal water institutions relative to female irrigators, by 0.526 units, ceteris paribus. Cheteni (2016) found a positive association between gender and farmer awareness of biofuel crops. He argued that male farmers obtain information faster than female farmers, and thus tend to have a higher level of awareness on agricultural activities or innovations.

A statistically significant $(p<0.01)$ and positive association between formal education and farmers' awareness of formal water institutions was found as anticipated. Irrigators who have received formal education were more aware of formal water institutions, by 0.335 units, than those with no formal education, ceteris paribus. According to Duhan and Singh (2017), the level of education directly influences the level of awareness and the correlation between education and awareness level is high. They found a positive relationship between the level of education and farmer awareness of crop insurance.

The estimated coefficient of scheme location (Msinga) was found to have a negative and statistically significant $(p<0.01)$ relationship with farmer awareness of formal water institutions. Irrigators in Msinga are less aware of formal water institutions than irrigators in Jozini by 0.536 units, ceteris paribus. This significant discrepancy between farmer awareness across these locations could be associated with differences in the accessibility of information and different sources of information.

A statistically significant $(p<0.01)$ and positive relation was found between farmer awareness of formal water institutions and water management training. Irrigators who had received water management training were more aware of formal water institutions, by 0.399 units, compared to those who have not received the training.

The estimated coefficient of farmer involvement in scheme decision-making processes was found to be a positive and statistically significant relationship $(p<0.05)$, as anticipated. An increase in farmer involvement in the scheme decisionmaking processes increases farmer awareness of formal water institutions by 0.096 units, ceteris paribus. Participation in decision-making processes in the scheme causes irrigators to be aware and updated about new water laws implemented at the central level, given that the scheme committee is also aware of formal water institutions.

\section{Factors influencing farmer awareness of informal water institutions in smallholder irrigations schemes}

The regression results presented in Table 7 show that farmer perceptions of the informal institutions governing the scheme were influenced by the role played by an irrigator in scheme leadership (ROLE_SCHMLED), government involvement in SISs (GOVT_INV), tribal authority involvement in SISs (TRIBAUTH_INV) and farmer involvement in scheme decision-making processes (INV_SCHMDEC). The $R^{2}$ was 0.2940 implying that $29.40 \%$ of the farmer awareness of the scheme governance is explained by the explanatory variables included in the model.

Formal education (FORMAL_EDUC), scheme location (SCHEME_LOC), farmer involvement in the scheme decisionmaking processes (INV_SCHMDEC) and the source of information (INFO_SOURCE) had a statistically significant influence in rule enforcement in the scheme. The $R^{2}$ for the model is 0.2613 , implying that $26.13 \%$ of the variation in rule enforcement in the scheme is explained by the explanatory variables included in the model.

\section{Farmer awareness of informal institutions governing the scheme}

A negative and statistically significant relationship between the role played by an irrigator in the scheme leadership implies that being in the scheme leadership reduces farmer 
awareness of informal institutions governing the scheme. This relationship contradicts prior expectations of the study. This can be attributed to the dominance of irrigators who are not part of the scheme committee, since this involves only very few irrigators in the scheme. The positive and statistically significant $(p<0.001)$ association between government and tribal authority involvement in SISs and farmer involvement in scheme decision-making processes and farmer perceptions of informal institutions in the scheme is consistent with the study expectations. Scheme governance involves various stakeholders such as government departments, traditional leaders, irrigators and the scheme committee, who work together for effective water management. In farmer discussions in MRIS, it became apparent that advisors from the local Department of Agriculture and Rural Development (DARD) are aware of the scheme governance as they work with irrigators, providing advisory services, implements and farm inputs. The involvement of tribal authorities in SISs increases farmer awareness of informal institutions governing the scheme. This is because all the study irrigation schemes are located in traditionally oriented areas where the authority of taditional leaders is most respected and obeyed. It was evident from focus group discussions that tribal authorities are aware of the operations in the scheme and know the scheme rules. They are also involved in the disciplining of non-compliance. Attending scheme meetings and participating in decision-making processes in the scheme improves farmer awareness of informal institutions governing the scheme. They are aware and updated about amendments in the scheme rules and scheme leadership.

\section{Enforcement of rules in the scheme}

Formal education revealed a positive and statistically significant relationship with rule enforcement in the scheme, implying that irrigators who have received formal education are more informed about the significance of rule enforcement. Hence, they were more aware that rules are enforced in the scheme. A positive association was found between the location of an irrigation scheme, farmer involvement in the scheme decisionmaking processes and farmer awareness of rule enforcement in the scheme. Irrigators in the Msinga Irrigation Scheme and farmers who participate in scheme decision-making processes are more likely to be aware of the rule enforcement in the scheme. This is because there are high incidents of unlawful behaviour and water conflicts in Msinga irrigation schemes compared to Jozini irrigation schemes. It is often difficult to report unlawful behaviour and impose penalties on irrigators due to fear of death however, there were some cases where irrigators were disciplined and matters are taken to traditional leaders. In this way, irrigators become aware that rules are enforced in the scheme. During the decision-making process issues of non-compliance, the possible punishments to be imposed and the effective ways of enforcing rules in the scheme are often discussed. The source of information does not inform irrigators about rule enforcement in the scheme.

\section{CONCLUSION AND RECOMMENDATIONS}

The study concludes that formal water institutions are unknown at the farm level, reflecting insufficient communication between government officials and irrigators. Instead, irrigators in SISs rely on informal institutional arrangements for water management. Formal water management institutions such as WUAs are unknown and/or non-existent. Results revealed that male irrigators were more aware of formal institutions than their female counterparts. This is because male farmers obtain information faster than female irrigators. In addition, customary laws and social norms in the study areas promote patriarchal power and limit women from participating in public organizations, local water governance, and decision-making processes, as traditionally they are expected to do homestead activities. Age of irrigator did not influence farmer awareness of both formal and informal water institutions in Mooi River, Tugela Ferry and Ndumo Irrigation Scheme.

The study recommends that for the NWA to achieve its goals, it is important that tribal authorities and irrigators should be made aware of the national laws, what they entail and their aims. In SISs irrigators tend to comply with rules locally set by traditional leaders which causes informal water institutions to be preferred to formal institutions. In addition, customary laws should be given recognition and incorporated when formulating national laws.

\section{ACKNOWLEDGEMENTS}

The author would like to thank the Water Research Commission (WRC) and the Department of Agriculture, Forestry and Fisheries for funding this study through WRC Project No. $\mathrm{K} 5 / 2556 / 4$ initiated, managed and funded by the WRC and entitled, 'Assessment of policies and strategies for the governance of smallholder irrigation farming in KwaZulu-Natal Province, South Africa',

\section{REFERENCES}

AKROUSH S and TELLERIA R (2013) Farmers' perceptions of water policies: A case study from the Jordanian Badia. International Center for Agricultural Research in the Dry Areas (ICARDA). ICARDA Working Paper 21.

CHETENI P (2016) Smallholder farmers' awareness of biofuel crops in the Eastern Cape Province, South Africa. MPRA Paper No. 77356. Munich Personal RePEc Archive (MPRA). https://doi.org/10.21511/ ee.07(3).2016.09

DENBY K (2013) Institutional integration and local level water access in the Inkomati catchment management area, South Africa. PhD thesis, Norwegian University of Life Sciences.

DERIBE R (2008) Institutional analysis of water management on communal irrigation systems in Ethiopia: the case of Atsbi Wemberta, Tigray Region and Ada'a Woreda, Oromiya Region. PhD thesis, Addis Ababa University.

DUHAN A and DHINGRA M (2018) Association between the factors affecting awareness level of farmers about agriculture insurance in Haryana. Int. J. Bus. Gen. Manage. 7 (1) 17-24. https://doi. org/10.9734/AJAEES/2017/37966

DUHAN A and SINGH S (2017) Factors affecting awareness level of farmers about crop insurance: A case study of Haryana. Asian J. Agric. Extension Econ. Sociol. 21 (4) 1-7. https://doi.org/10.9734/ AJAEES/2017/37966

EVERITT B and HOTHORN T (2011) An Introduction to Applied Multivariate Analysis with R. Springer, New York. https://doi. org/10.1007/978-1-4419-9650-3

GALLAHER S and HEIKKILA T (2014) Challenges and opportunities for collecting and sharing data on water governance institutions. J. Contemp. Water Res. Educ. 153 (1) 66-78. https://doi. org/10.1111/j.1936-704X.2014.03181.x

GUJARATI DN and PORTER DC (2009) Basic Econometrics. McGraw Hill Inc., New York.

KAISER HF and RICE J (1974) Little jiffy, mark IV. Educ. Psychol. Measure.34(1) 111-117.https://doi.org/10.1177/001316447403400115

MANZUNGU E (2002) More than a headcount: towards strategic stakeholder representation in catchment management in South Africa and Zimbabwe. Phys. Chem. Earth 27 927-933. https://doi. org/10.1016/S1474-7065(02)00095-5

MEINZEN-DICK R and NKONYA L (2005) Understanding legal pluralism in water rights: lessons from Africa and Asia. In: Proceedings of the International workshop - African Water Laws: Plural Legislative Frameworks for Rural Water Management in Africa, 26-28 January 2005, Johannesburg, South Africa.

MEHTA L, ALBA R, BOLDING A, DENBY K, DERMAN B, HOVE 
T, MANZUNGU E, MOVIK S, PRABHAKARAN P and VAN KOPPEN B (2014) The politics of IWRM in Southern Africa. Int. J. Water Resour. Dev. 30 (3) 528-542. https://doi.org/10.1080/0790062 7.2014.916200

MJOLI N, NENZHELELE R and NJIRO E (2009) Assessment of gender equity in water user associations. WRC Report No. KV 219/09. Water Research Commission, Pretoria.

MOWO J, ADIMASSU Z, CATACUTAN D, TANUI J, MASUKI K and LYAMCHAI C (2013) The importance of local traditional institutions in the management of natural resources in the highlands of East Africa. Human Org. 72 (2) 154-163. https://doi.org/10.17730/ humo.72.2.e1x3101741127x35

MUATHA IT (2014) An analysis of farmers awareness of agricultural extension devolution and preferences for participatory design of agricultural extension programs in Kenya. Masters thesis, The University of Nairobi.

MUCHARA B (2014) The economics of smallholder irrigation water management: institutions, water-use values and farmer participation in KwaZulu-Natal, South Africa. PhD thesis, University of KwaZulu-Natal.

MUDEGE NN, MDEGE N, ABIDIN PE and BHATASARA S (2017) The role of gender norms in access to agricultural training in Chikwawa and Phalombe, Malawi. Gender Place Culture 24 (12) 1689-1710. https://doi.org/10.1080/0966369X.2017.1383363

NAMARA RE, HANJRA MA, CASTILLO GE, RAVNBORG HM, SMITH L and VAN KOPPEN B (2010) Agricultural water management and poverty linkages. Agric. Water Manage. 97 (4) 520-527. https://doi.org/10.1016/j.agwat.2009.05.007

OKPEKE MY, OKORODUDU BO and ONYEAGOCHA SUO (2015) Assessment of farmers'awareness of the economic importance of physic nut (Jatropha curcas) in Ndokwa east local government area,
Delta State, Nigeria. Glob. J. Agric. Res. 3 (4) 34-49.

RSA (Republic of South Africa) (1998) National Water Act (No. 36 of 1998). Government Gazette 19182. Government Printer, Cape Town.

SCHNEGG M and BOLLIG M (2016) Institutions put to the test: Community-based water management in Namibia during a drought. J. Arid Environ. 124 62-71. https://doi.org/10.1016/j. jaridenv.2015.07.009

SINGH D and CHAUDHARY FS (1986) Theory And Analysis Of Sample Survey Designs. New Age International, New Delhi.

SINYOLO S, MUDHARA M and WALE E (2014) Water security and rural household food security: Empirical evidence from the Mzinyathi district in South Africa. Food Secur. 6 (4) 483-499. https://doi.org/10.1007/s12571-014-0358-0

SOKILE CS, MWARUVANDA W and VAN KOPPEN B (2005) Integrated water resource management in Tanzania: Interface between formal and informal institutions. In: Proceedings of the International workshop - African Water Laws: Plural Legislative Frameworks for Rural Water Management in Africa, 26-28 January 2005, Johannesburg, South Africa.

DWA (Department of Water Affairs, South Africa) (2013) National Water Resource Strategy Second edition. URL: http://www.dwa. gov.za/documents/Other/Strategic\%20Plan/NWRS2-Final-emailversion.pdf (Accessed 7 July 2018).

TSHUMA MC and MONDE N (2012) A socio-economic impact assessment of a project to identify and implement best management practices at the Zanyokwe Irrigation Scheme at farm level. Water SA 38 (5) 783-792. https://doi.org/10.4314/wsa.v38i5.18

WOOD SA, JINA AS, JAIN M, KRISTJANSON P and DEFRIES RS (2014) Smallholder farmer cropping decisions related to climate variability across multiple regions. Glob. Environ. Change $25163-$ 172. https://doi.org/10.1016/j.gloenvcha.2013.12.011 